\title{
Coast Guard Interdictions and the Use of Advanced Technology by Adversaries
}

\author{
Susan Pickman ${ }^{1, ~ *, ~ L a w r e n c e ~ A . ~ H o w a r d ~}{ }^{2}$ \\ ${ }^{1}$ Department of Security, Fire, and Emergency Management, John Jay College of Criminal Justice, New York, USA \\ ${ }^{2}$ Global Business and Transportation Department, SUNY Maritime College, Throggs Neck, USA
}

Email address:

spickman@jjay.cuny.edu (S. Pickman)

${ }^{*}$ Corresponding author

\section{To cite this article:}

Susan Pickman, Lawrence A. Howard. Coast Guard Interdictions and the Use of Advanced Technology by Adversaries. American Journal of Engineering and Technology Management. Vol. 5, No. 6, 2020, pp. 96-102. doi: 10.11648/j.ajetm.20200506.12

Received: February 19, 2020; Accepted: May 18, 2020; Published: December 31, 2020

\begin{abstract}
This paper reviews the history of the United States Coast Guard (USCG) and its ever-expanding and evolving security mission, both in the present day and into the future. The authors begin by describing the broad history of maritime crime, from piracy and smuggling to political terrorism and human trafficking. The paper next hones in on the creation and transformation of the USCG - from essentially a seagoing force charged primarily with protecting the fledgling U.S. government's main source of revenue through tariffs, to a key, multifaceted organization under the Department of Homeland Security (DHS) charged with no less than 11 major missions on both land and sea-a transformation that is ongoing to the present day. The paper identifies the increasing variety of both air and sea vessels that international criminals and cartels use to conduct drug smuggling and human trafficking, and even for the purpose of launching terrorist attacks. Today these methods include not just traditional means, like ships and planes, but also seemingly outlandish devices like flying drones and unmanned submersibles that can be-and have been-used to move all manner of contraband. The authors go on to describe the innovative technologies the USCG is employing to combat all of these diverse threats, including highly sophisticated intelligence gathering capabilities and all manner of high-tech digital scanning technology specifically aimed at more effective contraband detection. Finally, the paper concludes by highlighting the most pressing current and future security challenges that the USCG faces, and emanating from some very surprising origins: the use of evolving digital technology to support covert illegal operations, and the worldwide, international effort to stop the spread of the most dangerous pandemic in over 100 years.
\end{abstract}

Keywords: United States Coast Guard, Drug Smuggling, Contraband, Maritime Crimes, Submarines, Drones, Coronavirus

\section{Introduction}

Two hundred and twenty-eight years into the life of the United States Coast Guard (USCG), an old but vital mission, security, is suddenly thought of as a "new" mission for the organization. While many of the security challenges the USCG faces are essentially the same as they have ever been, technology and globalization have in many ways transformed both the USCG and its adversaries, creating new and more sophisticated challenges that require equally sophisticated and innovative solutions, as well as greater vigilance than ever before.

\section{History of Maritime Crimes}

Homeland security is by no means new; in some of its earliest security engagements, the USCG fought British Royal Navy Units (e.g., 1812 Battle of Little River [37]), enforced anti-slave trade law [4], and engaged pirates. Waterways, in fact, have been used as criminal highways since some of the earliest days of civilization. As long ago as $1350 \mathrm{BCE}$, piracy - that is, criminal acts (e.g., violence, detention, plundering) committed for private gain by members of one ship against another ("Maritime piracy law," n.d.) [25] — was recorded on trade routes in and around Egypt [5], and across the Mediterranean between Cyprus, Egypt, 
Levantine Coast, and in and around the Aegean Sea [9]. And while literature and folklore have fashioned comical images of peg-legged men wearing bandanas and eye patches strutting across splintery wooden plankways, piracy has been a serious threat to national and economic security across the centuries and continues to be so today. For instance, since 1960 , more than $\$ 100$ billion worth of oil has gone missing, and while only a small percentage of the oil was taken at sea, "given the scale of losses overall it is safe to assume that the value of oil stolen at sea makes Nigerian piracy the most lucrative in the world" [26].

In addition to piracy, smuggling is another issue affecting waterway security. Smuggling is most often associated with the illegal movement of illegal goods (such as contraband weaponry, i.e., arms trafficking, or illegal drugs, i.e., drug trafficking), but it can also refer to the movement of otherwise legal goods that are (or were) restricted or controlled (for any number of reasons) or taxed in some way. (By illegally transporting the goods from one country to another, purveyors avoid certain sales taxes or embargoes.) Smuggling, historically, has often taken place through maritime means [19] In fact, the U.S. Coast Guard has been engaged in contraband interdiction for almost 230 years since the establishment of the U.S. Revenue Cutter Service in August of 1790 upon the recommendation of Treasury Secretary Alexander Hamilton. Some 80 years later, as Rosen notes, "In 1870, Chinese immigrants became the first known drug smugglers when they began smuggling opium in merchant ship cargoes and baggage. The first documented opium seizure was made by Revenue Cutter Walcott on August 31, 1890, when it boarded the steamer George E. Starr" [35].

Today, smuggling is not limited to maritime means, but it is often executed by hiding goods in sealed shipping containers or secretively concealed vessel compartments; by strategically transferring goods from "mother ships" to smaller accomplice vessels such as trawlers and pleasure craft; and by being dropped from airplanes to small boats [2]. In recent drug trafficking cases, for instance, smugglers have transported up to $900 \mathrm{lbs}$ of marijuana via salvage barges and "go-fast" speedboats [11, 14]. However, criminals are also becoming more sophisticated. The use of semi-submersible vessels (specifically submarines) is becoming more popular-U.S. authorities estimate that over 60 submarines move over 300 metric tons of cocaine per year, most of which ends up in the U.S. [13].

Perhaps the most despicable form of smuggling involves human beings themselves. According to the nonprofit organization DoSomething, it is estimated that about 50,000 people are trafficked into the U.S. annually, mostly from Mexico and the Philippines [12]. The Human Trafficking Institute reported that for the year of 2018, over half over half $(51.6 \%)$ of the criminal human trafficking cases active in the US were sex trafficking cases involving only children [39]. Moreover, the unconscionable manner of transport of human trafficking victims is often abhorrently no better than that of smuggled hard goods or illegal drugs. In recent years there have been numerous incidents around the world in which migrants have been left to die horrifically inside sealed shipping containers or abandoned truck trailers.

A final security concern that has increased over the last 50 years or so - and perhaps the most ominously troubling one of all-is maritime terrorism. In her book Maritime Security and the Law of the Sea, Natalie Klein states that while "The United Nations Secretary-General has acknowledged that there is no agreed definition of 'maritime security'," there are activities that are commonly perceived as threats to maritime security, one of which is "terrorist acts involving shipping, offshore installations, and other maritime interests in the view of the widespread effects, including significant economic impact, that may result from such an attack" [21]. There are a number of examples that demonstrate the varying political and religious agendas that motivate these acts of terrorism. In 1961, Portuguese and Spanish Rebels hijacked a Lisboeta cruise ship to bring attention to fascist regimes in Portugal and Spain [31]. In October 1985, terrorists boarded a cruise ship in coastal waters of Egypt and threatened to kill the passengers unless 50 Palestinians held in Israel were released [31]. And in February 2004, the Abu Sayyaf terrorist group, along with the Jemaah Islamiyah and the Rajah Soliaman revolutionary movements detonated a bomb onboard of the Superferry 14 passenger ferry traveling from Manila Harbor to the South Philippines, killing 116 people $[18,31]$. This act of terror was performed because Abu Sayyaf "claims to promote an independent Islamic state in western Mindanao and Archipelago" [40].

\section{Old Mission, New Context}

As demonstrated by this robust history of maritime crimes, the need for a coast guard is not unique, nor is it new. Yet over time, it is certainly true that the purpose and operations of the USCG have evolved and expanded significantly.

As noted earlier, the USCG was actually first established as the "Revenue Cutter Service" in the 1790 Tariff Act through the enactment of the first income tax after the ratification of the Sixteenth Amendment in 1913. In short, this organization served as the protector of the fledgling United States government's primary source of revenue. Shortly after the income tax was implemented, the Revenue Cutter Service was merged with the United States Life Saving Service in 1915; the organization became the United States Coast Guard; and its mission expanded from interdicting smugglers and actively enforcing trade law to enforcing all federal maritime law, especially issues involving safety and navigation [32].

The latter part of the organization's mission was buttressed by several bureaucratic mergers. First, in 1939, the nation's Lighthouse Service was made part of the USCG. Then, in 1946, the Bureau of Marine Inspection and Navigation became part of the USCG, making it responsible for merchant marine licensing and safety inspection of merchant marine vessels.

Two more significant milestones in the organizational metamorphosis of the USCG were its 1967 transfer from the 
Treasury to the newly established Department of Transportation (DOT), and finally, in 2002, its inclusion in the newly created Department of Homeland Security (DHS) in the aftermath of the attack on America by Al Qaeda terrorists on September 11, 2001. The transfer to DOT confirmed that safety and navigation had become the Coast Guard's primary mission, but, suddenly, the transfer to DHS stressed stunningly the importance of national security, and once against thrust the Coast Guard into the front lines to protect America.

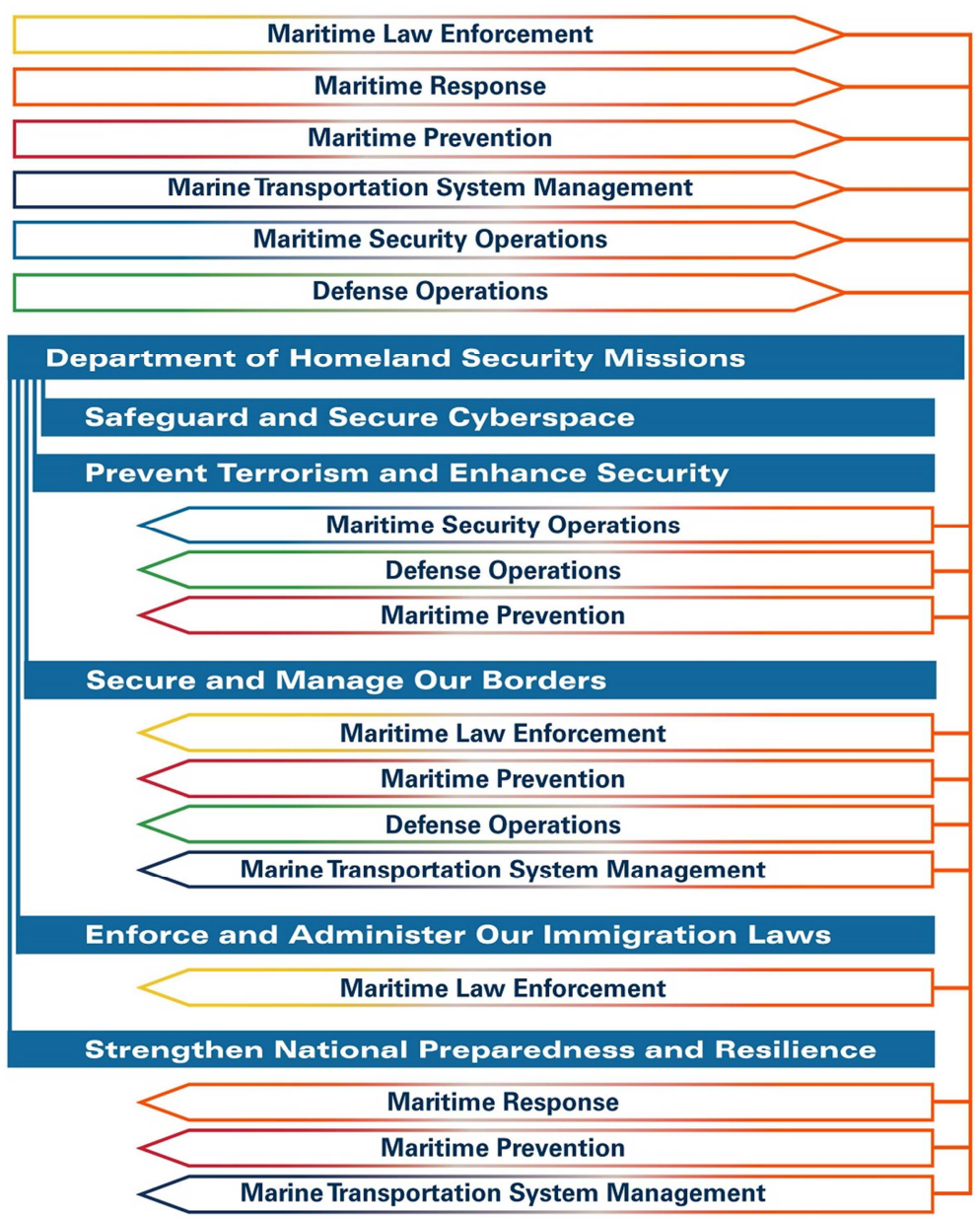

Figure 1. The Coast Guard manages six major operational mission programs overseeing 11 missions codified in the Homeland Security Act of 2002. (United States Coast Guard Missions, n.d.)

Today, the USCG has 11 major missions: ports, waterways and coastal security; drug interdiction; aids to navigation; search and rescue; living marine resources; marine safety; defense readiness (national security and military preparedness); migrant interdiction; maritime environment protection; polar, ice, and Alaska operations; and law enforcement. Seventeen years after $9 / 11$, security is the flip side of the safety mission; in fact, it is common to use the phrase "maritime safety and security"-for instance, the USCG has established maritime safety and security teams [15]. Who knows when a safety inspection might suddenly transform into a security incident?

\section{Technological Support of the Security Mission}

The 1790 Tariff Act that created the Revenue Cutter Service provided for the building of ten cutters. They were not uniformly designed, but generally measured from thirtysix to forty feet in length, and were manned by two officers and six marines each [24].

The initial cutters apparently were quite capably up to the crucial security missions assigned to the Revenue Cutter Service. Documentation is scarce for events prior to the War of 1812 because logs were lost, but we know that the early cutters:

acquitted themselves well in 1799 during the "Quasi War" with France, capturing most of the French prizes taken by Americans [6];

captured British merchant prizes during the War of 1812, won battles with British naval vessels, and earned (documented) admiration of the enemy [6];

dealt strong blows against Caribbean pirates, including the infamous Jean Lafitte [22];

interdicted slave traders after Congress outlawed the importation of slaves in 1808 - one example, in 1820, being the Revenue Cutter Dallas, which captured the brig Antelope 
with 280 slaves aboard [33];

defeated many smuggling operations. For example, records show that a cutter built in 1817, Vigilant, captured a smuggler brig near Block Island, Rhode Island, in 1818. The smugglers were armed with cannons, flew the Spanish flag, had a 30man crew, and were trying to offload contraband of brandy, silk, and other commodities [41].

The cutters proved resilient, and the officers and crew exhibited admirable courage and intelligence; they were used as a military service during war.
Today's USCG fleet boasts the new National Security Cutter $[28,29]$. This versatile vessel is 418 feet long, with a beam of 54 feet; its displacement is 4500 long tons; its maximum speed is 28 knots; it has a range of 12,000 nautical miles; it can endure 60- to 90-day cycles, and it can hold a 148-person crew [44]. Technological advances supply it with higher sustained transit speeds, better endurance and range, and the capacity to launch and recover small boats from the stern. Importantly, it also contains the latest computerized command and control, intelligence gathering, and aviation facilities.

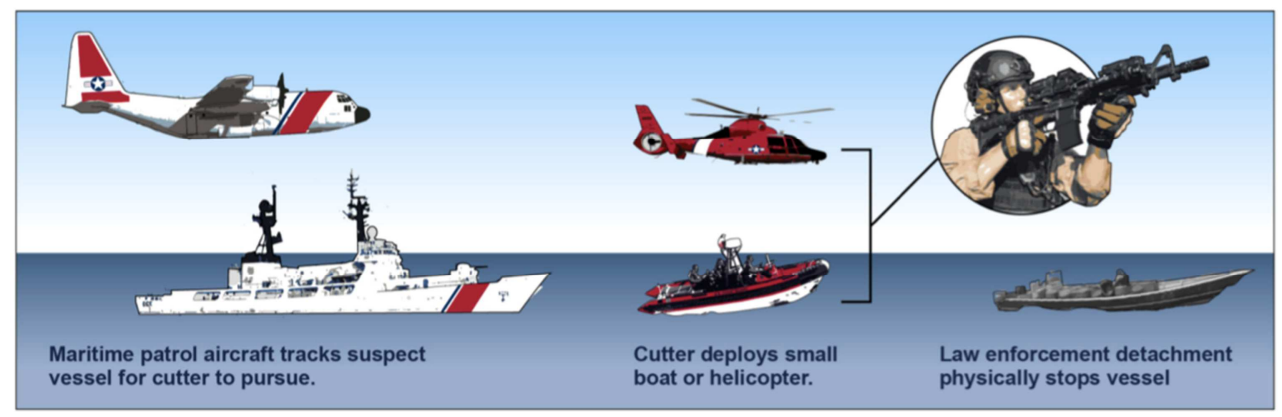

Figure 2. How the Coast Guard National Security Cutter is used to support drug interdiction operations.

Source: Coast guard: Resources provided for drug interdiction operations in the transit zone, Puerto Rico, and the U.S. Virgin Islands (United States Government Accountability Office \& Caldwell, 2014)

The USCG is also looking to further expand its portfolio of enforcement resources by adapting the use of drones to the execution of its security missions [16]. One such device is the unmanned aerial vehicle (UAV), which can be used for reconnaissance or attack missions deemed too dangerous for humans to undertake. "Processing UAVs for land-based and shipboard use will add great flexibility and increase the scope of operations" [47].

The inclusion in recent years of the National Security Cutter and drones in the USCG portfolio of resources is appropriate in the context of the deadly range of evasive and/or hostile threats that criminal and political adversaries present in the form of innovative simplification and use of advanced technology. Some examples of these threats include: building and deployment by drug cartels of semi-submersible and fully submersible vessels to smuggle drugs; some semisubmersibles are autonomous and have no onboard human crew $[1,3,30]$

flying drones that move lightweight narcotics across the border [10]

use of drones by terrorists to attack civilians and conventional military forces $[7,17]$

People generally think of advanced technology as expensive and something that only governments and big corporations can afford. This is true to an extent, but it is also false in many respects. The smartphone that most people carry around with them is an example of inexpensive, advanced technology that both expands and conditions our ability to interact with each other. Criminals use smartphones, too; generally, so-called "burners," or phones that can be purchased anonymously at a convenience store. As burners are typically only used once or twice, it is extremely difficult to track their location, listen in on conversations, and identify the user. Manufacturer lot numbers and retail records may be helpful in a given law enforcement investigation, but criminals are well aware of this and they do everything they can to minimize vulnerabilities.

Not only that, but today semi-submersibles and submarines are examples of advanced technology that can be built by relatively unskilled labor under a jungle canopy, as opposed to a big, expensive shipyards, and today's GPS technology means that these underwater craft do not require trained navigators to drive the finished product. In contrast to smartphones, the vessels built and deployed by drug cartels, for example, are not "burners"; rather, they are usually kept in continuous service until they break down or are apprehended. The big advantage of these types of vessels is that they are difficult to detect on radar and their low surface profile even makes them hard to see by the naked human eye.

Nor does the threat from submersible vessels come only from illegal cartels or drug and contraband smuggling operations. A March 2020 Forbes Magazine article recently revealed that, combining submersible capability with drone technology, in 2019 China had deployed between 12 and 14 drone submarines throughout the Indian Ocean [38]. Also referred to as underwater gliders, these sophisticated unmanned vehicles have spawned the name for a new class of submersibles: the Uncrewed Underwater Vehicle, or UUV.

Ostensibly used to gather oceanographic data such as seawater temperature, salinity, oxygen levels, and other factors, such scientific information is not as innocuous as it might seem on the surface. In fact, this kind of data is commonly gathered for naval intelligence relevant to submarine warfare; salinity, for example has a direct impact 
on how soundwaves travel through seawater, thus affecting how far away submarines may be heard by listening devices.

It seems inevitable that potentially hostile foreign regimes or governments, and even some friendly ones-not to mention potential terrorist organizations - will ultimately engage UUVs in coastal waters against United States for espionage and a host of other covert operations that will pose potentially significant threats to our national security-if they haven't done so already. If and when they do, one thing is abundantly clear: the USCG will play a major role in monitoring, confronting, and defeating any such threats.

Meanwhile in the skies, flying drones can be purchased off the shelf, although the technology is not at all hard for a hobbyist or enthusiast, paid well by a drug cartel or terrorist organization, to build. The antecedent of today's drones is the Radio Controlled (RC) model airplane. It was perhaps somewhat prophetic, given the lineage, that an $\mathrm{RC}$ plane was used to deliver a terrorist bomb in an old television script for an episode of the popular sixties series, The Man From U.N.C.L.E. [34].

ISIS used drones to drop bombs on civilian markets and military personnel in Iraq; the terrorists started out by using off-the-shelf products, and modified them to carry and drop hand grenades. The enemy graduated to improvising its own drone construction, an activity comparable to making improvised explosive devices and other homemade weapons. It is an easy transition from using drones to fly in drugs to using drones to attack USCG or other assets. In fact the threat of drones is so significant that the US Army developed a weapon that can be used in the field to destroy drones [20].

In the wake of a drone penetrating White House airspace, improved radar designed to detect items as small as a drone was developed and deployed [36]. It should therefore come as no surprise that the National Security Cutter has improved radar and sonar. Eight new cutters have also been authorized for the Coast Guard, and the design is being used by the Navy for guided missile frigates, as well ("Legend class," 2014). However, the role of USCG drone detection is by no means limited to the open water. In his annual State of the Coast Guard address on February 20, 2020, Admiral Karl Schultz, Commandant of USCG noted proudly that "for the first time ever, we employed Department of Homeland Security recently congressionally authorized counter-drone authorities to protect 130 world leaders who gathered at the United Nations General Assembly [in the fall of 2019]."

Of course, interdiction for a variety of reasons on the seas and waterways remains a major responsibility of the USCG. "Go-Fast" boats were used during Prohibition by bootleggers; the modern go-fast boat is used by drug smugglers [8]. The "cigarette boat," a long, narrow, low-to-the water craft, is a variation on the theme of "go-fast." A current, popular design is made of fiberglass, which is very hard to detect on radar. The National Security Cutter is designed to negate the advantages of such watercraft. They will be seen on the NSC's radar, and they cannot escape the cutter thanks in large measure to the air support that it carries with it.

\section{Present and Future Security Challenges}

The USCG has been successful in whatever roles have been required throughout its history. For instance, consider drug interdiction: Since the beginning of 2019 alone, the agency has intercepted more than 100 vessels, seized 100 tons of cocaine, and arrested more than 400 suspects in drug transit areas in the eastern Pacific Ocean [27]. In fact, approximately $52 \%$ of the total U.S. government seizures of cocaine can be attributed to the USCG [43]. However, the challenges agency is currently facing, and will face for the foreseeable future, involve missions of Homeland Security_namely countering terrorism, illegal drugs, contraband, and immigration, which are more complex issues than the agency has ever faced before.

Modern, sophisticated intelligence gathering will be crucial to fulfilling these security missions. However, the USCG alone cannot gather all of the intelligence it needs to keep the nation safe. Its present and future challenge is to efficiently and effectively gather intelligence from across all the U.S. agencies, integrate and make sense of the collective knowledge, and deploy resources accordingly. This is a tall order, and while technology in many ways can help (e.g., communicating quickly between agencies stationed around the world), it can also complicate the task at hand. Data scientists will undoubtedly play a role in the future of USCG.

The other major challenge the USCG is currently facing and will continue to face for years to come is the issue of national stabilization. Nation stabilization requirements will be more nuanced and complex than most of the Coast Guard missions to date; yet this mission is crucial to maritime security. The number of drop points available to modern-day smugglers and the technological advances U.S. adversaries have achieved make it imperative to enlist the assistance of governments that may not always be friendly or necessarily free of corruption. Furthermore, when military conflicts, natural disasters, and other large-scale issues destabilize areas of the world on which the United States relies or interacts, the nation's security is put in jeopardy.

For example, there are particular concerns about the drugs flowing through Puerto Rico and the U.S. Virgin Islands. Cocaine flow in particular has more than doubled in recent years, from 6.4 metric tons in fiscal year 2009 to 17.3 metric tons in fiscal year 2013 [45]. Meanwhile, recent hurricanes have devastated these islands, destabilizing the communities and law enforcement within them, and giving an even broader opening to criminal elements. This is an issue of national security that the USCG must address, and impending and inevitable climate change disasters will only make the mission that much harder.

Finally, just when the men and women of the USCG might have imagined that the nature and scope of the Coast Guard's responsibilities are about as fully evolved and defined as they might ever be, in this very year of 2020, along comes an altogether new and largely unanticipated threat to national security and the welfare of the nation-and a silent and invisible one at that-in the form of the pandemic of the 
deadly coronavirus known as Covid19.

In an on-line article published by the U.S. Naval Institute, Commandant Adm. Karl Schultz pointed out that, owing to its role nested within the Department of Homeland Security, the Coast Guard is the one branch of the military that is closest to the critical U.S. government response to the pandemic [46]. Summing up the Coast Guard's efforts on the front lines helping to try to protect America, Adm. Schultz stated, "We're intimately involved. About 4,000 ships a month call on the United States. About 750 in the Pacific. We're screening every one of those ships."

\section{Conclusion}

The relentless battle against human traffickers, smugglers, terrorists, and other criminals - and now today against a viral invader - continues without any foreseeable end. It is a fight as old as human maritime interactions, yet now in the $21^{\text {st }}$ Century also carried out above and below the surface of the world's oceans - as well as through the digital electronic ether of cyberspace. However, it is a fight in which the USCG has exceptionally acquitted itself for over 200 years. In the modern era, as it has throughout its distinguished history, the USCG continues to step up to confront the new and varied security challenges faced by the nation, whenever and wherever the service has been asked to do so. With technological advancements, human innovation, and dogged persistence, the agency will prevail in strengthening homeland security and keeping the nation safe. As Commandant Adm. Karl Schultz proudly stated in his 2020 State of the Coast Guard address, "Our service has never been more relevant."

\section{Competing Interests}

The authors declare that they have no conflict of interest.

\section{References}

[1] Anderson, B. (2015, August). The hunt for narco subs. Motherboard. Retrieved from https://motherboard.vice.com/en us/article/the-hunt-for-narcosubs

[2] Bichler, G. (2011). Maritime crime. In M. Natarajan (Ed.), International crime and justice (pp. 185-192). New York, NY: Cambridge University Press.

[3] Bowerman, M. (2017, December 11). U.S. Coast Guard intercepts semi-submersible vessel packed with 3,800 pounds of cocaine. USA Today. Retrieved from https://www.usatoday.com/story/news/nationnow/2017/12/11/u-s-coast-guard-intercepts-semi-submersiblevessel-packed-3-800-pounds-cocaine/939668001/

[4] Bumgarner, J. (2014). Federal law enforcement and human trafficking. In M. J. Palmiotto (Ed.), Combating human trafficking: A multidisciplinary approach (1st ed., p. 179). Boca Raton, FL: CRC Press.

[5] Chet, G. (2014). The ocean is a wilderness: Atlantic piracy and the limits of state authority, 1688-1856. Boston, MA:
University of Massachusetts Press.

[6] Collins, C. (2017, June 29). The revenue cutter service in the War of 1812. Defense Media Network. Retrieved from https://www.defensemedianetwork.com/stories/revenue-cutterservice-war-1812/

[7] Conditt, J. (2017, January 16). ISIS has converted commercial drones into bombers. Engadget. https://www.engadget.com/2017/01/16/isis-dronesweaponized-bombers-iraq-mosul/

[8] Corcoran, K. (2015, January 19). Drug cartels using new 'gofast' boats that are almost invisible to radar on Central American smuggling missions. UK Daily Mail Online. Retrieved from http://www.dailymail.co.uk/news/article2913854/Drug-cartels-using-new-fast-boats-INVISIBLEradar-Central-American-smuggling-missions.html

[9] De Souza, P. (1999). Piracy in the Graeco-Roman world. Cambridge, United Kingdom: Cambridge University Press.

[10] Dinan, S. (2017, August 20). Mexican drug cartels using drones to smuggle heroin, meth, cocaine into U.S. The Washington Times. Retrieved from https://www.washingtontimes.com/news/2017/aug/20/mexica n-drug-cartels-using-drones-to-smuggle-heroi/

[11] D'Ocon, L. (2014, August 16). U.S. Coast Guard confiscates 900 pounds of marijuana headed for Miami. Miami Herald. Retrieved from http://www.miamiherald.com/

[12] DoSomething.org. (2020). 11 Facts about human trafficking. Retrieved from https://www.dosomething.org/us/facts/11facts-about-human-trafficking

[13] Dudley, S. S. (2010). Drug trafficking organizations in Central America: Transportistas, Mexican cartels and maras. In E. L. Olson, D. A. Shirk, and A. Selee (Eds.), Shared responsibility: U.S.-Mexico policy options for confronting organized crime (pp. 63-93). Washington, D.C.: Woodrow Wilson International Center for Scholars: Mexico Institute \& University of San Diego: Trans-Border Institute.

[14] Fuss, C. M. (1996). Sea of grass: The maritime drug war, 1970-1990. Annapolis, MD: Naval Institute Press.

[15] Hallock, A. (2018, January 12). Honor, respect, devotion to duty: Maritime Safety and Security Team Miami. Coast Guard Compass, Official Blog. Retrieved from http://coastguard.dodlive.mil/2018/01/hrdd-maritime-safetyand-security-team-miami/

[16] Haring, L. (2017, August 14). U.S. Coast Guard looks to drones to expand its reach. Maritime Executive. Retrieved from https://www.maritime-executive.com/article/us-coastguard-looks-to-drones-to-expand-its-reach\#gs.GpCfWXE

[17] Home-made drones now threaten conventional armed forces. (2018, February 8). Economist. https://www.economist.com/news/science-andtechnology/21736498-their-small-size-and-large-numberscan-overwhelm-defences-home-made-drones-now

[18] Human Rights Watch. (2007). Lives destroyed: Attacks against civilians in the Philippines. Retrieved from https://www.hrw.org/

[19] Karras, A. L. (2010). Smuggling: Contraband and corruption in world history. Lanham, MD: Rowman \& Littlefield Publishers. 
[20] Keller, J. (2017, April 26). The army is preparing to field this electromagnetic rifle against ISIS drones. Task and Purpose. Retrieved from https://taskandpurpose.com/isis-drones-armydronedefender-rifle

[21] Klein, N. (2011). Maritime security and the law of the sea. New York, NY: Oxford University Press.

[22] Lagan, C. (2010, March 4). History: The piracy mission - then and now. Compass. Retrieved from http://coastguard.dodlive.mil/2010/03/history-the-piracymission-then-and-now/

[23] Legend class National Security Cutter. (2014). Naval Technology. Retrieved from https://www.navaltechnology.com/projects/legendclassnsc/

[24] Leonard, C. (2013, August 4). The U.S. Congress created the revenue-marine toady in 1790, the forerunner of our modern United States Coast Guard. Now We Know Em. Retrieved from https://nowweknowem.wordpress.com/2013/08/04/the-us-congress-created-the-revenue-marine-toady-in-1790-theforerunner-of-our-modern-united-states-coast-guard-now-weknow-em/

[25] Maritime piracy law and legal definition. (n.d.). USLegal.com. Retrieved from https://definitions.uslegal.com $/ \mathrm{m} /$ maritime-piracy/

[26] Murphy, M. N. (2013). Petro-piracy: Oil and troubled waters. Orbis, 57 (3), 424-437.

[27] National Security Cutter. (2020). Retrieved from https://www.dcms.uscg.mil/Our-Organization/AssistantCommandant-for-Acquisitions-CG-9/Programs/SurfacePrograms/National-Security-Cutter/

[28] National Security Cutter. (2018). Military.com. Retrieved from https://www.military.com/equipment/national-securitycutter

[29] Nixon, R. (2018, March 1). Departing commandant lays out coast guard's successes and challenges. The New York Times. Retrieved from https://www.nytimes.com/2018/03/01/us/politics/state-of-thecoast-guard.html

[30] Popkin, J. (2013, October). How a high school-educated drug smuggler built a fleet of submarines - in the middle of the jungleto ferry cocaine to the United States. Slate. Retrieved from http:/www.slate.com/articles/news_and_politics/foreigners/2013/1 $0 /$ mauner mahecha s drug submarines inside a high tech south american_narco.html

[31] Power, J. (2008). Maritime terrorism: A new challenge for national and international security. Barry Law Review, 10, 111-133.

[32] Price, S. (2015, May 19). Historic mergers strengthened U.S. Coast Guard. Maritime Executive. Retrieved from https://www.maritime-executive.com/blog/historic-mergersstrengthened-us-coast-guard\#gs.f47dqW8

[33] Price, S. (2015, June 22). 225 years of service to nation: Migrant interdiction. Compass. Retrieved from http://coastguard.dodlive.mil/2015/06/225-years-of-service-tonation-migrant-interdiction/

[34] Richter, M. (2016, January 26). The man from U.N.C.L.E.: "The mad, mad tea party affair?" Preppies of the Apocalypse. $\mathrm{http}: / /$ preppiesoftheapocalypse.blogspot.com/2016/01/theman-from-uncle-mad-mad-tea-party.html
[35] Rosen, D. (2015, July 7). 225 years of service to nation: Drug interdiction. Retrieved from

$\mathrm{http}$ :/coastguard.dodlive.mil/2015/07/225-years-of-service-tonation-drug-interdiction/

[36] Scmidt, M. S., \& Shear, M. D. (2015, January 26). A drone, too small for radar to detect, rattles the white house. New York Times. Retrieved from

https://www.nytimes.com/2015/01/27/us/white-housedrone.html

[37] Sherbs, D. (2017, November 9). The long blue line: Commodore Barry and the Battle of Little River. Coast Guard Compass, Official Blog.

http://coastguard.dodlive.mil/2017/11/tlbl-commodore-barry/

[38] Sutton, H.I. (2020). China deployed 12 underwater drones in Indian Ocean. Forbes. Retrieved from https://www.forbes.com/sites/hisutton/2020/03/22/chinadeployed-underwater-drones-in-indian-ocean/amp/

[39] The Human Trafficking Institute. (2018). The federal human trafficking report. Retrieved from https://www.dosomething.org/us/facts/11-facts-about-humantrafficking

[40] The U.S. National Counterterrorism Center. (n.d.). Counterterrorism guide. Retrieved from https://www.dni.gov/nctc/index.html

[41] United States Coast Guard. (1989). Record of movements: Vessels of the US Coast Guard, 1790-December 31, 1933. Washington, DC: Department of Transportation, U.S. Coast Guard.

[42] "United States Coast Guard Missions." (n.d.). Retrieved from https://www.work.uscg.mil/Missions/

[43] United States Congress House Committee on Transportation and Infrastructure, Subcommittee on Coast Guard and Maritime Transportation. (2009). Overview of Coast Guard drug and migrant interdiction: Hearing before the subcommittee on Coast Guard and Maritime Transportation of the Committee on Transportation and Infrastructure, House of Representatives, One Hundred Eleventh Congress, First Session, March 11, 2009. Washington: U.S. G.P.O.

[44] United States Government Accountability Office. (2013). Coast guard: Better logistics planning needed to aid operational decisions related to the deployment of the national security cutter and its support assets. Washington, D.C.: U.S. Govt. Accountability Office.

[45] United States Government Accountability Office \& Caldwell, S. (2014). Coast guard: Resources provided for drug interdiction operations in the transit zone, Puerto Rico, and the U.S. Virgin Islands: Report to congressional requesters. Washington, D.C.: United States Government Accountability Office. Retrieved from https://www.gao.gov/assets/670/664098.pdf

[46] U.S. Naval Institute News. (2020). Coast Guard key to coronavirus U.S. response. Retrieved from https://news.usni.org/2020/03/02/coast-guard-key-tocoronavirus-u-s-response-marines-navy-increasing-measuresto-ward-off-disease-spread

[47] Walsh, A., \& Air University Center for Strategy and Technology. (2003). Homeland security and the coast guard: Postured for technology improvements (Occasional paper, no. 33). Maxwell Air Force Base, AL: Center for Strategy and Technology, Air War College, Air University. 